\title{
THE CONSTRUCTION OF URBAN PUBLIC SPORTS SERVICE FROM THE PERSPECTIVE OF PUBLIC HEALTH
}

\author{
CONSTRUÇÃO DE SERVIÇOS DESPORTIVOS PUUBLICOS URBANOS SOB A PERSPECTIVA DA SAÚDE PÚBLICA
}

Xiaolong Zhang' (iD

(Basic Medicine)

1. General Education Institute, Huanghai University, Qingdao, Shandong Province, China.

Correspondence:

Qingdao, Shandong Province, China.qxhgts@163.com

\begin{abstract}
With the deepening of urban public sports service construction in China, the construction of public sports service system has become an important guarantee for mass sports rights in China. In view of this, this study takes City XX as an example, and analyzes the difference of public sports service construction in this city using the Theil index method, and determines the measurement index. It analyzes the equality degree of service resource allocation among and within the four regions of City XX, including A, B, C, D, and so on. The influencing factors of sports service efficiency are analyzed. The results show that there are significant differences in the allocation of public sports service resources among districts and counties of City XX. From the overall difference, the total Theil index of national fitness and sports clubs showed an upward trend, while others showed a downward trend. From the perspective of regional differences, there were 6 indicators with the highest equalization level in area $C$ and 5 indicators in area A. The lowest level was found. Population density, per capita GDP, aging rate and urbanization rate of city XX have obvious positive correlations with public sports service efficiency. The aging rate is the most positive factor, while per capita GDP and population density have little influence. This study can provide some reference value for other cities in China in the construction of public sports services.
\end{abstract}

Keywords: Public health; public sports; construction; service system.

\section{RESUMO}

Com o aprofundamento da construção de serviços públicos desportivos urbanos na China, a construção de um sistema público de serviço desportivo tornou-se uma importante garantia para o exercício dos direitos desportivos em massa na China. Em vista disso, este estudo toma a Cidade XX como exemplo, e analisa a diferença de construção de serviços públicos desportivo nessa Cidade pelo método índice de Theil, e determina o índice de medição. Analisa o grau de igualdade de alocação de recursos entre e dentro das quatro regiões da Cidade XX, incluindo as regiões $A, B, C, D$, e assim por diante. Os fatores que influenciam a eficiência do serviço esportivo são analisados. Os resultados mostram que há diferenças significativas na alocação de recursos públicos de serviços esportivos entre os distritos e condados da Cidade XX. A partir da diferença global, o índice total serviços de atividades físicas em âmbito nacional e clubes desportivos mostrou uma tendência ascendente, enquanto outros mostraram uma tendência descendente. Sob a perspectiva das diferenças regionais, havia seis indicadores com o mais alto nível de equalização na área C e 5 indicadores na área A. O nível mais baixo foi encontrado. A densidade populacional, o PIB per capita, a taxa de envelhecimento e taxa de urbanização da Cidade XX têm uma correlação positiva óbvia com a eficiência do serviço desportivo público. A taxa de envelhecimento é o fator mais positivo, enquanto o PIB per capita e a densidade populacional têm pouca influência. Este estudo pode fornecer algum valor de referência para outras cidades da China na construção de serviços desportivos públicos.

Descritores: Saúde pública; desporto público; construção; sistema de serviços.

\section{RESUMEN}

La profundización de la construcción de servicios deportivos públicos urbanos en China se ha convertido en una garantía importante para los derechos deportivos de masas en China. Ante esto, este estudio toma como ejemplo la Ciudad XX y analiza la diferencia de construcción de servicios públicos deportivos en esta ciudad utilizando el método del índice de Theil y determina el índice de medición. Verifica el grado de igualdad en la asignación de recursos de servicios entre y dentro de las cuatro regiones de la Ciudad XX incluyendo $A, B, C, D$, etc. También analiza los factores que influyen en la eficiencia del servicio deportivo. Los resultados muestran que existen diferencias significativas en la asignación de los recursos de los servicios deportivos públicos entre los distritos y condados de la Ciudad XX. A partir de la diferencia general, el indice de Theil total de los clubes deportivos y de educación física nacionales mostró una tendencia al alza, mientras que otros mostraron una tendencia a la baja. Desde la perspectiva de las diferencias regionales, se encontraron 6 indicadores con el nivel más alto de igualación en el área C y 5 indicadores en el área A. Se encontró también el nivel más bajo. 
La densidad de población, el PIB per cápita, la tasa de envejecimiento y la tasa de urbanización de la ciudad XX tienen evidentes correlaciones positivas con la eficiencia de los servicios deportivos públicos. La tasa de envejecimiento es el factor más positivo, mientras que el PIB per cápita y la densidad de población tienen poca influencia. Este estudio puede aportar algún valor de referencia para otras ciudades de China en la construcción de servicios deportivos públicos.

Descriptores: Saúde pública; Desporto público; construção; sistema de serviços.

DOI: http://dx.doi.org/10.1590/1517-8692202127012020_0104

Article received on 10/22/2020 accepted on 11/16/2020

\section{INTRODUCTION}

With the improvement of China's living and economic level, physical exercise has become an important way of people's activities. In order to make the quality of public health service goal oriented, process programmed and method standardized, the government has gradually improved the quality of public sports service, so that the masses can have a positive life experience and lifestyle, so as to achieve the purpose of improving the health of the whole people. ' The party and the government have always attached great importance to the development of mass sports, but due to the special domestic and foreign environment, it has become an inevitable path for China's sports cause to carry out competitive sports nationwide. ${ }^{2}$ After the 1980s, with the gradual recovery of China's economy, the sports industry has also reached a new height, and the demand for sports services of the masses has gradually increased, but there is still a certain gap with the world's sports powers. First of all, China's public sports development is slow, the investment in funds is relatively small, and the supply of resources is relatively small, which can not meet the growing sports demand of the masses The second is the poor competitive level of track and field, swimming and three major balls in China, which hinders the smooth development of sports construction in China. ${ }^{3}$ In order to make sports events not only add honor to the motherland, but also make them serve the masses, the construction of urban public sports services has become a major measure of our government to serve the people's livelihood. ${ }^{4}$ The vigorous promotion of public sports service construction is not only a measure to transform government functions, but also an inherent requirement of sports development and transformation. ${ }^{5}$ Based on the characteristics of urban public sports service construction, this study takes 11 districts and counties of XX City as the empirical basis, and studies the methods of urban public sports service construction from the perspective of public health.

Through the research of domestic and foreign scholars on the construction of public sports service, we can see that although domestic and foreign scholars are more enthusiastic about the construction of public sports service, the design based on the perspective of public health is still a blank state. Therefore, based on the construction strategy of public sports service, this study analyzes the construction of urban public sports service from the perspective of public health, aiming to provide certain reference value for the construction of urban public sports service in other areas in practice and theory.

\section{Research on the construction of urban public sports service}

This paper decomposes the influencing factors of four regions of XX city by Theil index, and analyzes the equality degree of service resource allocation among and within the four regions a, B, C and D. Table 1 shows the Theil index of each factor in the four regions in 2013 and 2017.

It can be seen from Table 1 that there are significant differences in the allocation of public sports service resources among districts and counties of XX city. On the whole, the thile index of national fitness, national fitness and sports clubs showed an upward trend, while the overall thile index of fitness compliance rate, number of fitness

Table1. Theil index of factors in four regions in 2013 and 2017.

\begin{tabular}{|c|c|c|c|c|c|c|c|c|c|}
\hline Influence factor & Year & Interregional & $\begin{array}{l}\text { Within the } \\
\text { region }\end{array}$ & Area A & Area B & Area C & Area D & $\begin{array}{c}\text { Interregional } \\
\text { contribution } \\
\text { rate }(\%)\end{array}$ & $\begin{array}{c}\text { Regional } \\
\text { contribution } \\
\text { rate (\%) } \\
\end{array}$ \\
\hline \multirow{2}{*}{ Expenditure } & 2013 & 0.0482 & 0.0593 & 0.0584 & 0.0181 & 0.0198 & 0.1005 & 44.83 & 55.18 \\
\hline & Mean value & 0.0547 & 0.0488 & 0.0529 & 0.0284 & 0.0071 & 0.0717 & 1 & 1 \\
\hline Site facilities & 2013 & 0.0863 & 0.0686 & 0.0006 & 0.2722 & 0.1117 & 0.0179 & 55.72 & 44.28 \\
\hline \multirow{3}{*}{ Athletic director } & 2013 & 0.0627 & 0.0642 & 0.1303 & 0.0788 & 0.0004 & 0.0185 & 49.42 & 50.58 \\
\hline & 2017 & 0.0528 & 0.0497 & 0.1074 & 0.0733 & 0.0128 & 0.0018 & 51.62 & 48.38 \\
\hline & Mean value & 0.0574 & 0.0654 & 0.1356 & 0.0887 & 0.0028 & 0.0122 & 1 & 1 \\
\hline \multirow[b]{2}{*}{ Social organization } & 2013 & 0.1245 & 0.0934 & 0.1984 & 0.1856 & 0.0499 & 0.0093 & 57.14 & 42.87 \\
\hline & 2017 & 0.0635 & 0.0868 & 0.2477 & 0.0839 & 0.0187 & 0.0053 & 42.18 & 57.82 \\
\hline \multirow{3}{*}{$\begin{array}{l}\text { National fitness } \\
\text { activities }\end{array}$} & 2013 & 0.2099 & 0.1674 & 0.1079 & 0.0553 & 0.0229 & 0.2481 & 55.64 & 44.38 \\
\hline & 2017 & 0.2223 & 0.1451 & 0.1992 & 0.0906 & 0.1608 & 0.1095 & 60.53 & 39.49 \\
\hline & Mean value & 0.1621 & 0.1508 & 0.1123 & 0.1861 & 0.0593 & 0.1708 & 1 & 1 \\
\hline \multirow{3}{*}{$\begin{array}{l}\text { National physical } \\
\text { examination }\end{array}$} & 2013 & 0.0543 & 0.0938 & 0.0232 & 0.2115 & 0.1891 & 0.0538 & 36.66 & 63.36 \\
\hline & 2017 & 0.0528 & 0.1948 & 0.0024 & 0.0752 & 0.0047 & 0.5288 & 21.38 & 78.64 \\
\hline & Mean value & 0.0926 & 0.1252 & 0.0583 & 0.1009 & 0.0607 & 0.2257 & 1 & 1 \\
\hline
\end{tabular}


activities, mass management institutions, sports associations, sports instructors, stadiums, and economic investment showed a downward trend. The comparison of the average value of 2017 and XX city is shown in the Figure 1 (Ning 2015).

From 2013 to 2017, the club allocation and national fitness path have the lowest equalization level, followed by the number of national fitness activities, while the higher level of resource allocation is the allocation of sports instructors, stadiums and funds, and other indicators are in the middle. From 2013 to 2017, the imbalance of the allocation and expenditure of public sports venues in XX city is caused by the differences among different regions. However, the regional differences lead to the low equalization level of indicators such as the rate of physical fitness monitoring, the number of people monitored, the mass sports management institutions, clubs, sports associations, sports instructors, and the national fitness path. The Thil index of the number of national activities fluctuates greatly, and the change of the impact on the total difference is also relatively repeated, with a low level of equalization. For the differences within the region, there are 6 indicators with the highest equalization level in area $\mathrm{C}$, which are the number of national fitness activities, the number of national fitness activities, the allocation of sports instructors, club allocation, mass sports management institutions and expenditure; there are three indicators with the highest level of equalization in area D, which are sports associations, fitness monitoring compliance rate and stadium allocation. ${ }^{3}$

Malmquist parameters of XX City in each year can be calculated to obtain continuously comparable DEA values from 2014 to 2017, and calculate the DEA efficiency frontier change index, where effch is the technical efficiency coefficient, techch is the technical change coefficient,

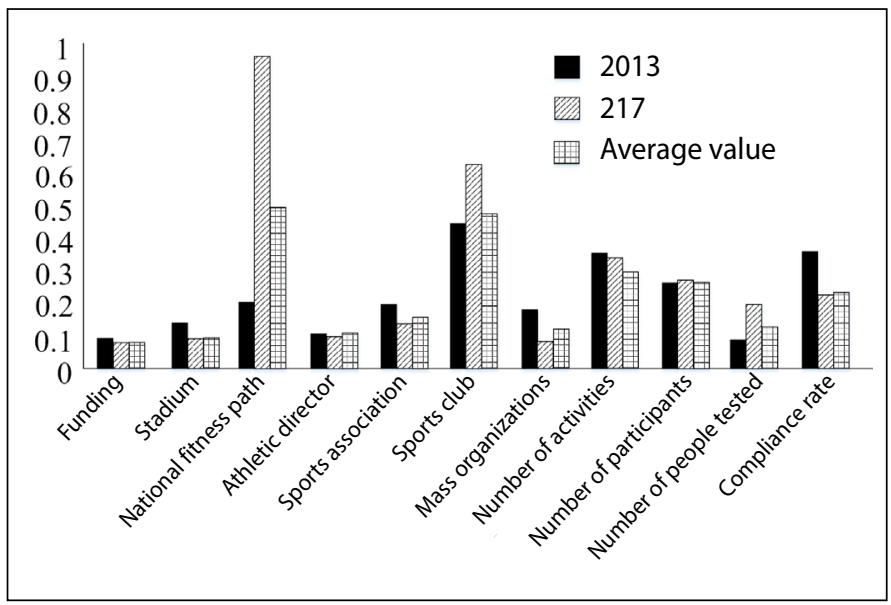

Figure 1. Comparison of Theil index 2013, 2017 and average value of public sports service resource allocation. tfpch is the total factor productivity coefficient. The calculation results are shown in Table 2.

The results in Table 2 are calculated by formula (7) model, and the results are shown in Table 3. In the panel data model of XX city about the relationship between their variables, the standard deviation of individual effect and random interference item is relatively small; the average value of Rho is greater than 0.59 , which reflects that individual change can be used to explain the efficiency of public sports service in different regions of XX city; from the logarithmic likelihood value, it can be seen that the model has a high degree of fitting. According to the estimation coefficients in Table 3 , it can be seen that the population density, per capita GDP, aging rate and urbanization rate of XX city have obvious positive correlation with the efficiency of public sports service. The aging rate is the most positive factor, and the per capita GDP and population density have little impact. ${ }^{3}$

In Table 3, P is the probability case of the parameter estimator. If $\mathrm{p}$ value is between $[0.05,0.1]$, parameter estimator is significant at $10 \%$; if $p$ value is between $[0.01,0.05]$, parameter estimator is significant at $5 \%$; if $p$ value is between $[0.00,0.01]$, parameter estimator is significant at $1 \%$. There is a positive correlation between the efficiency of public sports services and the aging rate. Since 2016, more than $60 \%$ of the elderly in XX city have participated in the exercise. Due to the high proportion of participants, the government will increase the efforts to invest in services, so when the aging rate rises, the positive impact on the efficiency of public sports services in XX city will be greater; public sports service efficiency and urbanization rate The urbanization rate has a significant positive impact on the efficiency of public sports service in XX city. Due to the obvious difference between urban and rural public sports service level, in fact, more urban residents participate in exercise. Even if public services such as national fitness test, national fitness activities, sports organizations, sports instructors and facilities

Table 3. Theil index of factors in four regions in 2013 and 2017

\begin{tabular}{c|c|c}
\hline Explanatory variable & Coefficient & P \\
\hline Constant term & 0.608 & 0.093 \\
\hline InUR & 0.137 & 0.086 \\
\hline InAR & 0.106 & 0.092 \\
\hline InPGDp & 0.014 & 0.122 \\
\hline InFD & 0.018 & 0.137 \\
\hline Standard deviation of individual effect & 0.053829 & 0.54246 \\
\hline RHOrd deviation of random interference & 0.042347 & 0.07077 \\
\hline Likelihood ratio test & 0.59 & 0.62 \\
\hline Log Likelihood & 150.06 & 133.2 \\
\hline \multicolumn{2}{|c|}{55} \\
\hline
\end{tabular}

Table 2. Theil index of factors in four regions in 2013 and 2017.

\begin{tabular}{|c|c|c|c|c|c|c|c|c|c|c|c|c|}
\hline \multirow{2}{*}{$\begin{array}{c}\text { district and } \\
\text { county }\end{array}$} & \multicolumn{3}{|c|}{2014} & \multicolumn{3}{|c|}{2015} & \multicolumn{3}{|c|}{2016} & \multicolumn{3}{|c|}{2017} \\
\hline & effch & techch & tfpch & effch & techch & tfpch & effch & techch & tfpch & effch & techch & tfpch \\
\hline $\mathrm{HZ}$ & 1.00 & 1.00 & 1.00 & 1.00 & 0.84 & 0.84 & 1.00 & 0.89 & 0.89 & 1.00 & 1.21 & 1.21 \\
\hline NB & 1.00 & 1.03 & 1.03 & 1.00 & 1.06 & 1.06 & 1.00 & 1.16 & 1.16 & 1.00 & 0.75 & 0.74 \\
\hline WZ & 0.97 & 1.03 & 1.00 & 1.22 & 1.10 & 1.34 & 1.00 & 0.88 & 0.88 & 1.00 & 0.95 & 0.95 \\
\hline$J X$ & 1.00 & 1.23 & 1.22 & 1.00 & 1.05 & 1.05 & 1.00 & 0.86 & 0.86 & 1.00 & 1.79 & 1.79 \\
\hline $\mathrm{HZ}$ & 1.00 & 0.92 & 0.92 & 0.89 & 0.91 & 0.82 & 1.11 & 1.01 & 1.12 & 1.00 & 1.53 & 1.53 \\
\hline $\mathrm{QZ}$ & 1.00 & 1.39 & 1.39 & 1.00 & 1.01 & 1.01 & 1.00 & 1.11 & 1.11 & 1.00 & 1.04 & 1.04 \\
\hline ZS & 1.00 & 1.04 & 1.04 & 1.00 & 1.09 & 1.09 & 1.00 & 0.83 & 0.83 & 1.00 & 0.91 & 0.91 \\
\hline $\mathrm{TZ}$ & 1.00 & 1.18 & 1.18 & 1.00 & 0.92 & 0.92 & 1.00 & 0.82 & 0.82 & 1.00 & 1.75 & 1.75 \\
\hline LS & 1.00 & 1.73 & 1.73 & 1.00 & 0.94 & 0.94 & 1.00 & 0.69 & 0.69 & 0.91 & 1.16 & 1.06 \\
\hline Mean value & 0.99 & 1.15 & 1.15 & 1.02 & 0.99 & 1.01 & 1.03 & 0.92 & 0.97 & 0.98 & 1.20 & 1.18 \\
\hline
\end{tabular}


are provided, the efficiency of public sports services will not increase with the increase of financial expenditure and economic expenditure, but will cause public sports The phenomenon of service congestion leads to lower efficiency and higher cost .

\section{CONCLUSIONS}

Based on the perspective of health, this study show that there are significant differences in the allocation of public sports service resources among districts and counties of XX city. From the overall difference, the total thile index of national fitness, national fitness and sports clubs showed an upward trend, while others showed a downward trend; from the perspective of regional differences, there were 6 indicators with the highest equalization level in area $\mathrm{C}$ and 5 indicators in area $\mathrm{A}$. There is a positive correlation between the efficiency of public sports service and the aging rate, the greater the positive impact of the increase of the aging rate on the efficiency of public sports service in XX city; there is a positive correlation between the efficiency of public sports service and the urbanization rate; the higher the urbanization rate, the greater the positive impact on the efficiency of public sports service in XX city; there is a weak positive correlation between the efficiency of public sports and the population density. The greater the efficiency of public sports services, the greater the efficiency of public sports services; public sports service efficiency and per capita GDP show a small positive impact, the efficiency of public sports services will not increase with the increase of financial and economic expenditure.

The author declare no potential conflict of interest related to this article

AUTHORS' CONTRIBUTIONS: The author has completed the writing of the article or the critical review of its knowledge content. This paper can be used as the final draft of the manuscript. Every author has made an important contribution to this manuscript. Xiaolong Zhang: writing and execution.

\section{REFERENCES}

1. Wolfgang M. Sports and martial arts activities for public health purposes: the musician's risk profiles and exercise-based health care as a model. Journal of Public Health. 2017; 25(3):231-241.

2. Long $X$, Xun L. Construction of community sports public health platform from the perspective of "Internet +" and "Healthy China". Shandong sports science and technology. 2019; 041(004):71-74.

3. Tianyu G, Jiawei L. Review and outlook: Commentary and Research on Public Service of Youth Sports
Health in China. Journal of Guangzhou Institute of Physical Education. 2019; 039(005):7-13.

4. Ning W. Service Mode and Mechanism of Public Sport Health Management in China. Journal of Shenyang Institute of Physical Education. 2015; 034(005):59-62,86.

5. Liu HC, Liu L, Liu N, et al. Risk evaluation in failure mode and effects analysis with extended VIKOR method under fuzzy environment. Expert Systems with Applications. 2012; 39(17):12926-12934. 